\title{
ANALYSIS OF STRENGTH CHARACTERISTICS IN RAILROAD DOWELS PRODUCED BY VARIOUS MANUFACTURERS
}

\author{
Dmitrii Nikitin", Liudmila Nikitina², Arthur Asoyan³, Alexey Marusin ${ }^{4}$ \\ ${ }^{1}$ Saratov State Vavilov Agrarian University \\ Teatralnaia sq., 1, Saratov, Russia \\ ${ }^{2}$ Yuri Gagarin State Technical University of Saratov \\ Politechnicheskaya st., 77, Saratov, Russia \\ ${ }^{3}$ Moscow Automobile and Road Construction State Technical University (MADI) \\ Leningradsky Av., 64, Moscow, Russia \\ ${ }^{4}$ Saint Petersburg State University of Architecture and Civil Engineering \\ Vtoraja Krasnoarmejskaja st., 4, St. Petersburg, Russia
}

\begin{abstract}
The article describes operating conditions of the railroad dowel used in ZhBR 65 resilient rail fasteners. Requirements for railroad dowel tests in terms of their expediency, possibility to perform such tests and conformity with the actual operating conditions are analyzed. The initiative of the authors, arisen during an analysis of regulatory documents, served as a basis for the studies. Stresses in a dowel and its safety factor in operation and tests were determined analytically by the finite element method, using the APM FEM library, the system of strength analysis for KOMPAS-3D, certified within the GOST-R system.

Railroad dowels manufactured by OOO NTT, ZAO Polimer ZAO and Vossloh Fastening Systems GmbH were used as study objects. For the purposes of simulation, $3 \mathrm{D}$ models of the corresponding dowels and their mating parts (sleeper, railroad screw, tension clamp, etc.) were built. According to the studies, in tensile tests of dowels, conducted according to Clause 4.6 of Specifications TsP 369 TU-7, stresses of $85 . .100 \mathrm{MPa}$ occur in the bodies of all dowels under consideration, which considerably exceed stresses appearing in dowels during operation, and the nature and distribution of such stresses do not correspond to those of operating stresses, the maximum value of which does not exceed $10 \mathrm{MPa}$.

The analysis of stresses arising in sleepers with dowels by the manufacturers under consideration has shown that their limit value is $75 \mathrm{MPa}$. Besides, in sleepers with dowels by OOO NTT and Vossloh Fastening Systems GmbH, the maximum stresses are in the sleeper body, which allows for their redistribution and prevents dowel pulling-out from a sleeper. Sleepers with dowels made by ZAO Polimer have maximum stresses in the upper face of a sleeper coaxially with the dowel axis, which significantly increases the probability of dowel pulling-out in case of extreme loads.
\end{abstract}

\section{Keywords}

Railroad dowel, rail fastener, track structure, internal stresses, yield strength, ultimate strength, safety factor.

\section{Introduction}

A railway track, the structure and maintenance of which are specified in a number of regulatory documents, represents the basic element of the railroad transport infrastructure (Ministry of Railways, 2001, 2003; Russian Railways, 2013). Rail fasteners play an important role in reliability of the track structure (Karpushchenko, 2007; Karpushchenko, Antonov, 2003; Kuznetsov, Eremushkin, 2006), which is why their structure (as the structure of their components) is constantly improved and tested.
Since the beginning of the 2000 s, in the railroad sector of Russia, resilient rail fasteners have been mainly used as they provide immobility of rail bars and reliability of their fastening during operation due to firmer contact between a rail and a foundation, ensured by a tension clamp, regardless of the ambient temperature.

A general view of a rail fastener is given in Figure 1.

As follows from this figure, track 1 is laid on sleeper 2 over rail pad 7 and fastened using dowel 8 and screw 3. In transverse direction, the track is fastened by side 


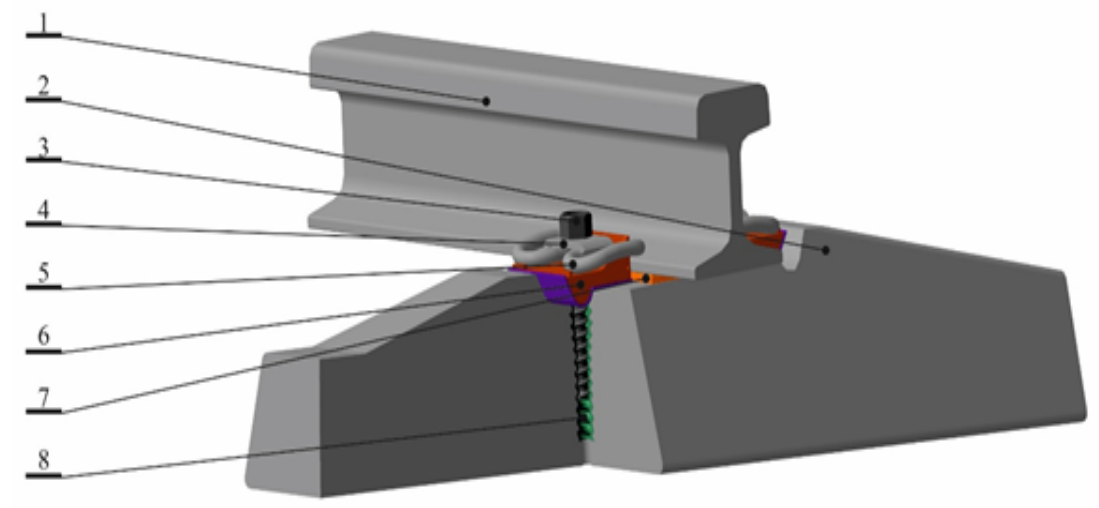

Figure 1. A general view of a resilient screw/dowel rail fastener

1 - track, 2 - sleeper, 3 - screw, 4 - brace, 5 - tension clamp, 6 - side stop, 7 - rail pad, 8 - railroad dowel.

stops 6 , and vertically - by tension clamp 5 . The vertical pressing force of the track, as well as the load on the dowel and screw are determined only by the deformation force of the tension clamp (Russian Railways, 2013). In Russian Railways (2016), dowels manufactured by OOO NTT (Russian Railways, 2016; Nikitin et al., 2013, 2014], dowels manufactured by ZAO Polimer (VNIIZhT JSC, 2011; Borodin et al., 2013; Akimov et al., 2008; Akimov, 2006, 2009a, 2009b, 2011, 2012) and dowels manufactured by Vossloh Fastening Systems GmbH (2010) are used.

To manufacture dowels, OOO NTT uses its own polymer compound (Nikitin et al., 2009; Nikitina, Nikitin, 2013, 2015; Nikitina, Kosobudsky, 2016; Nikitina et al., 2013) based on polypropylene, ZAO Polimer uses Armlen PP-SV 10-2T, which is glass-filled polypropylene, and Vossloh Fastening Systems $\mathrm{GmbH}$ uses polyamide PA 6. Basic physical and mechanical properties of the materials are given in Table 1.

Table 1. Physical and mechanical properties of dowel materials.

\begin{tabular}{|l|l|l|}
\hline Indicator & $\begin{array}{l}\text { PP-SV } \\
10-2 T\end{array}$ & $\begin{array}{l}\text { Polyamide } \\
\text { PA 6 }\end{array}$ \\
\hline Yield strength [MPa] & 85 & 65 \\
\hline Normal modulus of elasticity [MPa] & 2,800 & 2,200 \\
\hline Poisson's ratio & 0.35 & 0.3 \\
\hline Density [kg/m3] & 990 & 1,135 \\
\hline $\begin{array}{l}\text { Thermal coefficient of linear ex- } \\
\text { pansion }\left[1 /{ }^{\circ} \mathrm{C}\right]\end{array}$ & 0.000012 & 0.000012 \\
\hline Thermal conductivity $\left[\mathrm{W} /\left(\mathrm{m} \cdot{ }^{\circ} \mathrm{C}\right)\right]$ & 1 & 1 \\
\hline Compression strength $[\mathrm{MPa}]$ & 60 & 410 \\
\hline Tensile fatigue limit $[\mathrm{MPa}]$ & 56 & 65 \\
\hline Torsional fatigue limit $[\mathrm{MPa}]$ & 139 & 139 \\
\hline
\end{tabular}

\section{tests.}

\section{Calculation of stresses arising in dowels in tensile}

Railroad dowels manufactured by OOO NTT (Figure 2a), ZAO Polimer (Figure 2b) and Vossloh Fastening Systems $\mathrm{GmbH}$ (Figure 2c) were used as the study objects. The subject of the study included strength characteristics of dowels made by different manufacturers, dowel structure impact on strength characteristics of sleepers, and justifiability of the requirements (Russian Railways, 2016). for the dowels of rail fasteners, which is conditioned both by the opinion of the manufacturers considering some requirements to be redundant and the issues brought up by the scientific community (Russian Railways, 2017; Dydyshko, 2009).

To model stresses and deformations occurring in dowels made by different manufacturers, as well as the safety factor during tests conducted according to Clause 4.6 (Russian Railways, 2016) (tensile tests), 3D models of the dowels cut short in the bottom, made as per recommendations (Alexandrova, Zaytseva, 2012, 2013; Bolshakov et al., 2010), were used. The head of the screw turned into the dowel from the bottom was rigidly fixed at its face surfaces, and the force of $5 \mathrm{kN}$ was applied to the "lower" face surface of the head of the "upper" dowel (Figure 3).
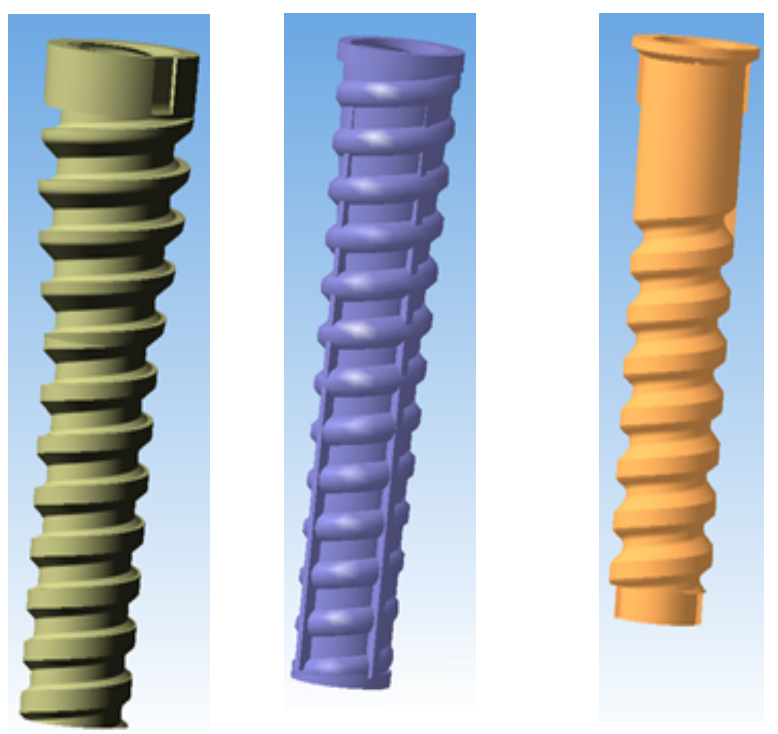

Figure 2. Appearance of dowels made by different manufacturers: a - OOO NTT, b - ZAO Polimer, c - Vossloh Fastening Systems $\mathrm{GmbH}$. 


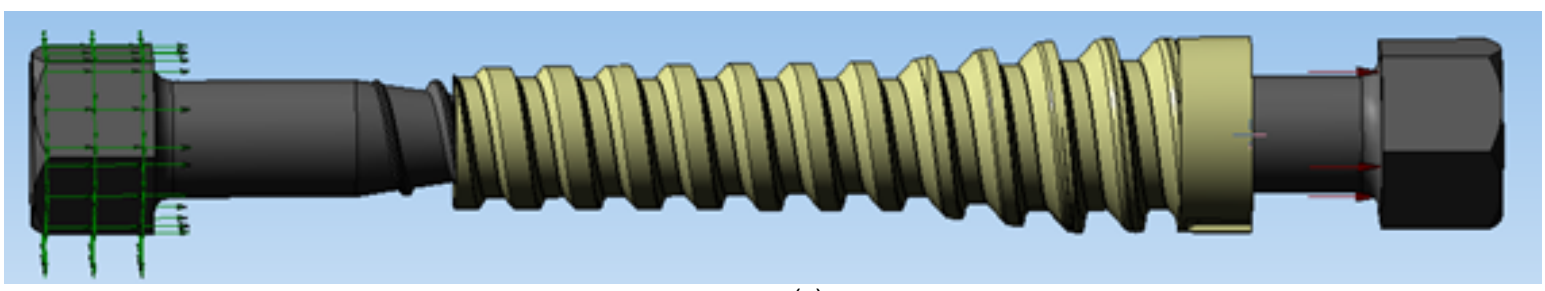

(a)

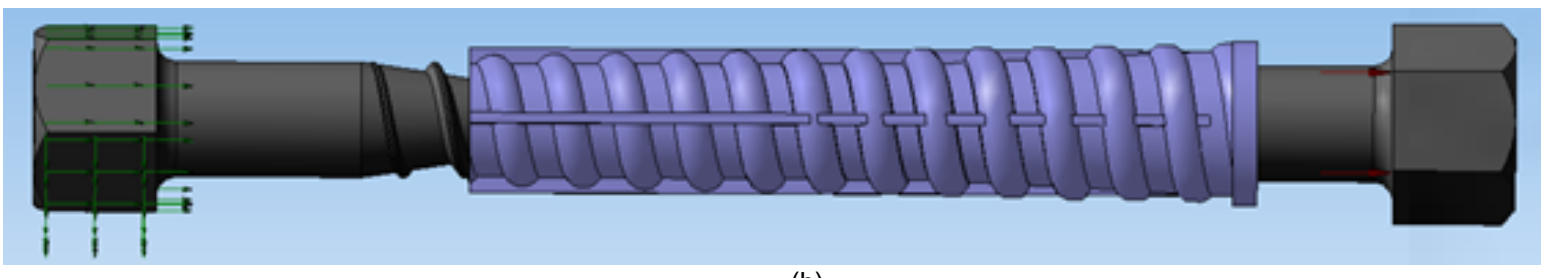

(b)

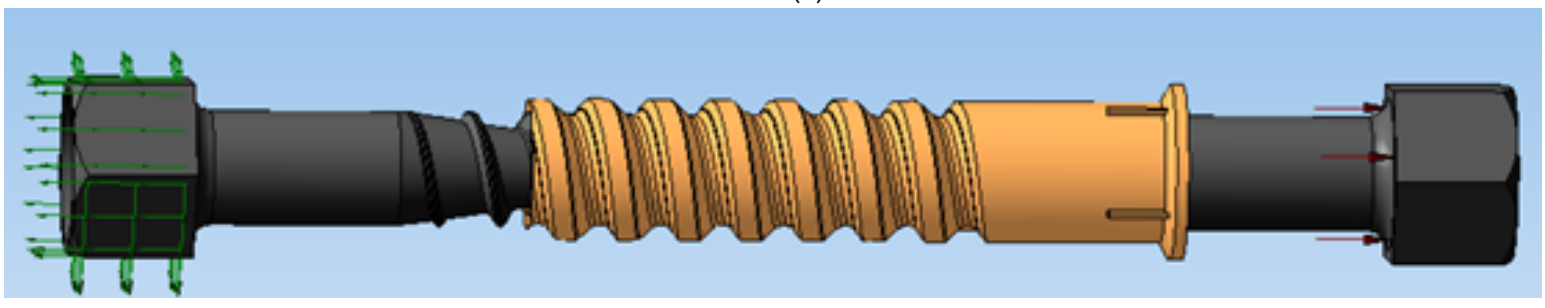

(c)

Figure 3. 3D models with the dowels, made by different manufacturers, cut short in the lower part a - OOO NTT, b - ZAO Polimer, c - Vossloh Fastening Systems GmbH.

To verify conformity of the model with the requirements (State Committee of the USSR for Standards, 1980), tensile tests were conducted.

During finite element (FE) division, a non-regular grid, 4-node tetrahedra with the element side length of $3 \mathrm{~mm}$, fine grid coefficient 5 and coarse grid coefficient 1.5, were used.

The results of the division are presented in Table 2.

Calculation of stresses in the dowels during tensile tests (according to the requirements (Russian Railways, 2016) has shown the following:

1. The maximum stresses [omax] in all dowels are 85...100 MPa (Figure 4).

2. All dowels have the maximum stresses on a relatively small area.
3. The nature of stress distribution is approximately the same in all dowels.

To find out if the strength is sufficient, the safety factor was calculated. The corresponding results are given in Figure 5. In the weakest cross-sections, the minimum values of the safety factor were the following: 3.64 for the dowels made by Vossloh Fastening Systems $\mathrm{GmbH}$, 0.58 for the dowels made by OOO NTT, and 0.74 for the dowels made by ZAO Polimer. Thus, only the dowels manufactured by Vossloh Fastening Systems $\mathrm{GmbH}$ can stand the tests.

However, it should be noted that during tests, stresses in all dowels are close in their values, and positive results obtained for the dowels made by Vossloh Fastening

Table 2. Division results.

\begin{tabular}{|c|c|c|}
\hline Manufacturer & Number of FEs & Division result \\
\hline OOO NTT & 639,504 & \\
\hline ZAO Polimer & $1,190,459$ & \\
\hline $\begin{array}{l}\text { Vossloh Fas-tening Systems } \\
\qquad \mathrm{GmbH}\end{array}$ & 172,168 & \\
\hline
\end{tabular}




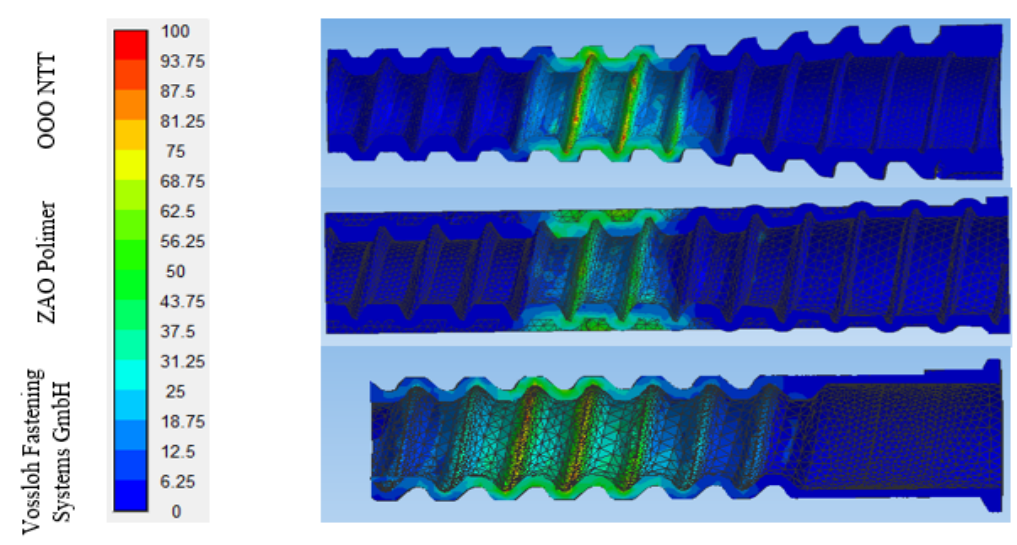

Figure 4. Distribution of stresses in the bodies of dowels, made by different manufacturers, during tensile tests, MPa.
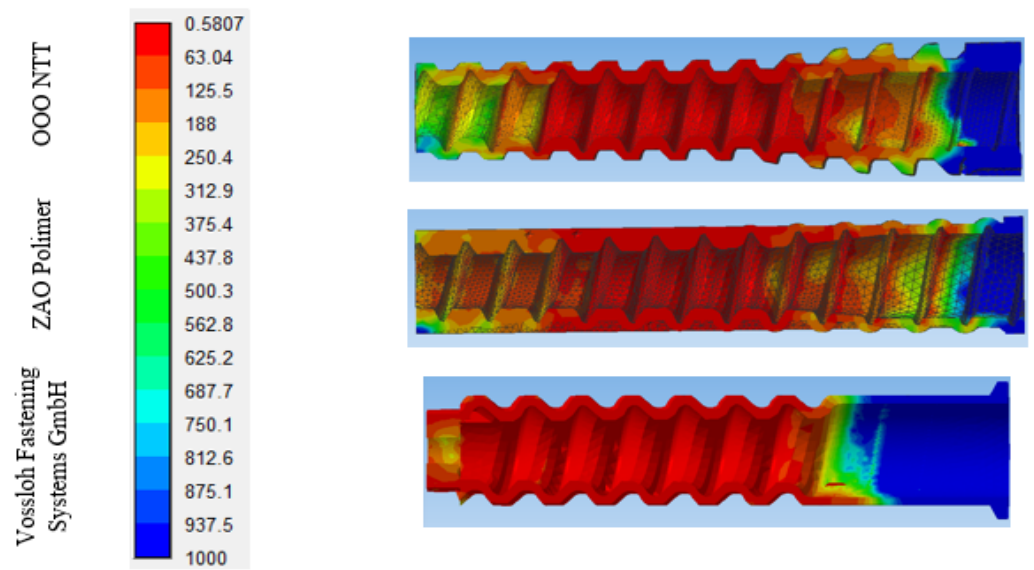

Figure 5. Safety factor distribution maps for stresses in the bodies of dowels, made by different manufacturers, during tensile tests.

Systems $\mathrm{GmbH}$ are determined by the material properties only, and not by the dowel structure.

In order to confirm (or deny) this statement, we have peformed similar calculations for the dowels made by OOO NTT and ZAP Polimer ZAO of polyamide, and the dowels made by Vossloh Fastening Systems $\mathrm{GmbH}$ of armlen. Under those conditions, the calculation results with regard to the safety factor distribution map were (minimum values) $2.6,4.8$ and 0.58 , respectively. The summary results of studying the strength characteristics of all dowels are given in Table 3 .

Table 3. Minimum safety factor values of dowels made by different manufacturers (in the weakest cross-sections).

\begin{tabular}{|l|l|l|}
\hline \multirow{2}{*}{ Manufacturer } & Dowel material \\
\cline { 2 - 3 } & Armlen & Polyamide \\
\hline OOO NTT & 0.58 & 2.6 \\
\hline ZAO Polimer & 0.74 & 4.8 \\
\hline $\begin{array}{l}\text { Vossloh Fastening } \\
\text { Systems GmbH }\end{array}$ & 0.58 & 3.64 \\
\hline
\end{tabular}

As follows from Table 3, the safety factors of dowels made by different manufacturers do not vary significantly, which means that their structures are of equal strength.

Intermediate conclusions:

1. The values of stresses occurring in the bodies of dowels under consideration in tensile tests are approximately the same.
2. The operating part of a dowel made according to the corresponding requirements (Karpushchenko, 2007) has higher stresses in the operating area.

3. A higher safety factor of a dowel made according to the corresponding requirements (Karpushchenko, 2007) (Vossloh) is determined only by the use of stronger and more expensive materials. When a dowel is made of armlen, as dowels made according to the corresponding Specifications and Instructions (Ministry of Railways, 2003; Russian Railways 2013), its strength characteristics do not exceed similar characteristics of dowels made according to such Specifications and Instructions (Ministry of Railways, 2003; Russian Railways 2013).

\section{Analysis of stresses and strength characteristics} of dowels in operation

In order to evaluate justifiability of the $5 \mathrm{kN}$ load applied to a dowel in tensile tests, let us determine stresses and safety factors in the body of a dowel while in operation.

Analytical 3D models are given in Figure 6.

With account for studies of Karpushchenko and Antonov (Karpushchenko, Antonov, 2003), the maximum axial force on a screw during installation is $4.1 \mathrm{kN}$, therefore, performing calculations, we will consider the load of $5 \mathrm{kN}$ (exceeding he standard value by $25 \%$ ) to be justified. However, it should be taken into account that sleeper load conditions differ from operating conditions significantly. As we do not consider the sleeper strength in this part of the study, in order to reduce the machining 


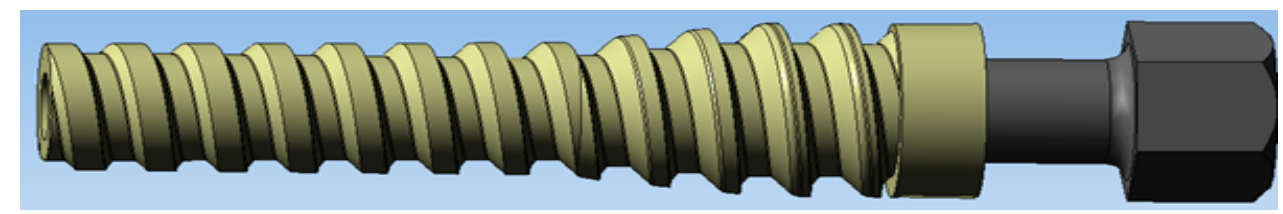

(a)

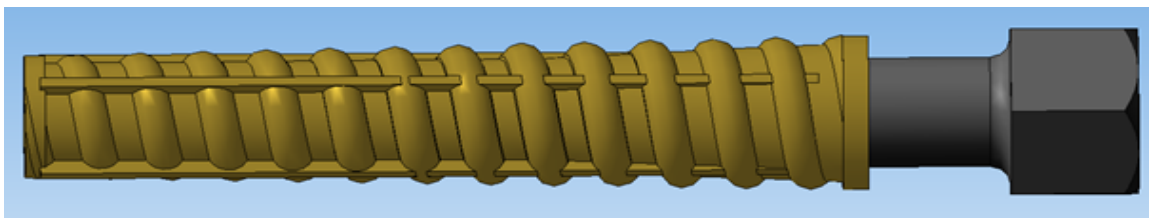

(b)

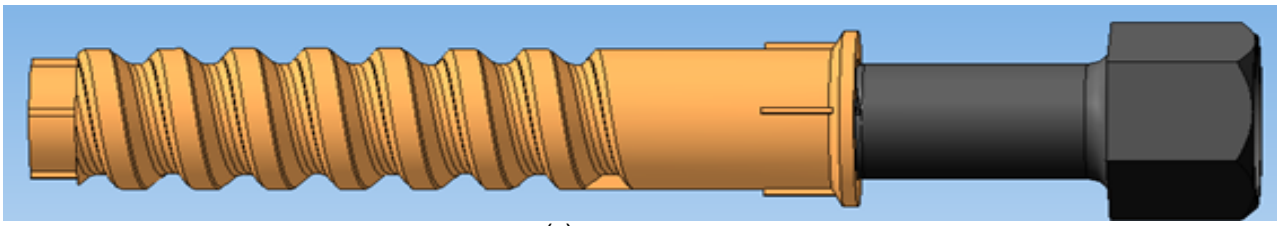

(c)

Figure 6. 3D models of dowels made by different manufacturers a - OOO NTT, b - ZAO Polimer, c - Vossloh Fastening Systems GmbH.

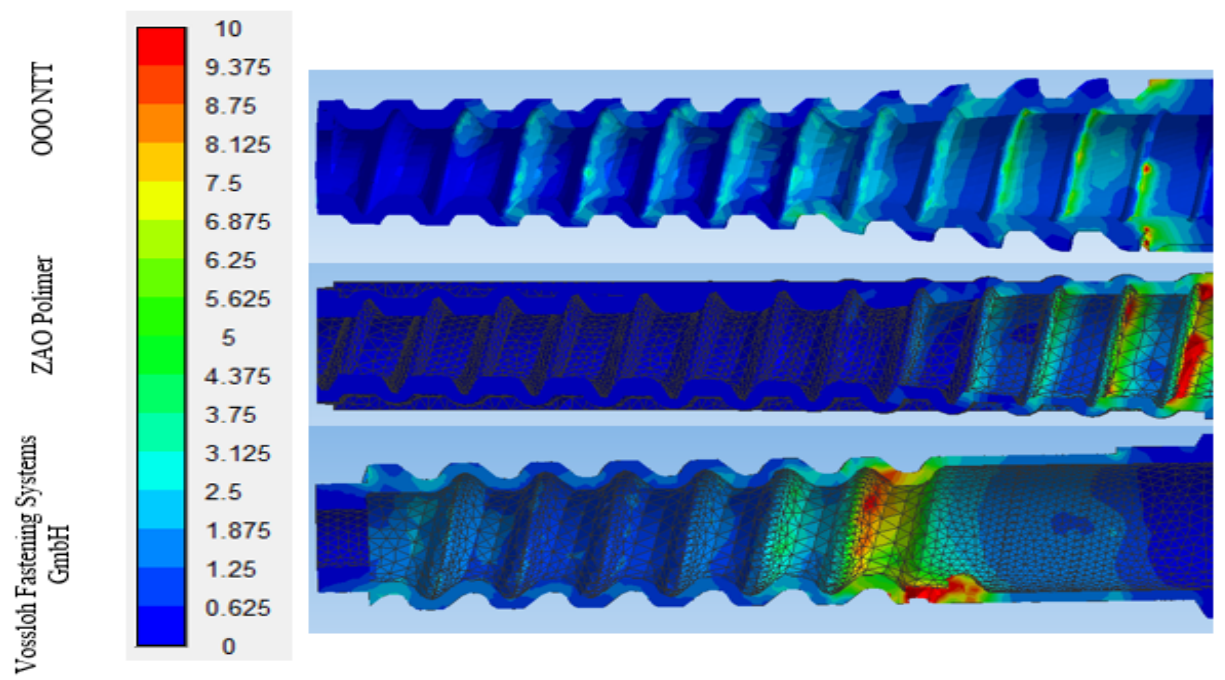

Figure 7. Distribution of stresses in the bodies of dowels, made by different manufacturers, at the operating load in a sleeper, MPa.

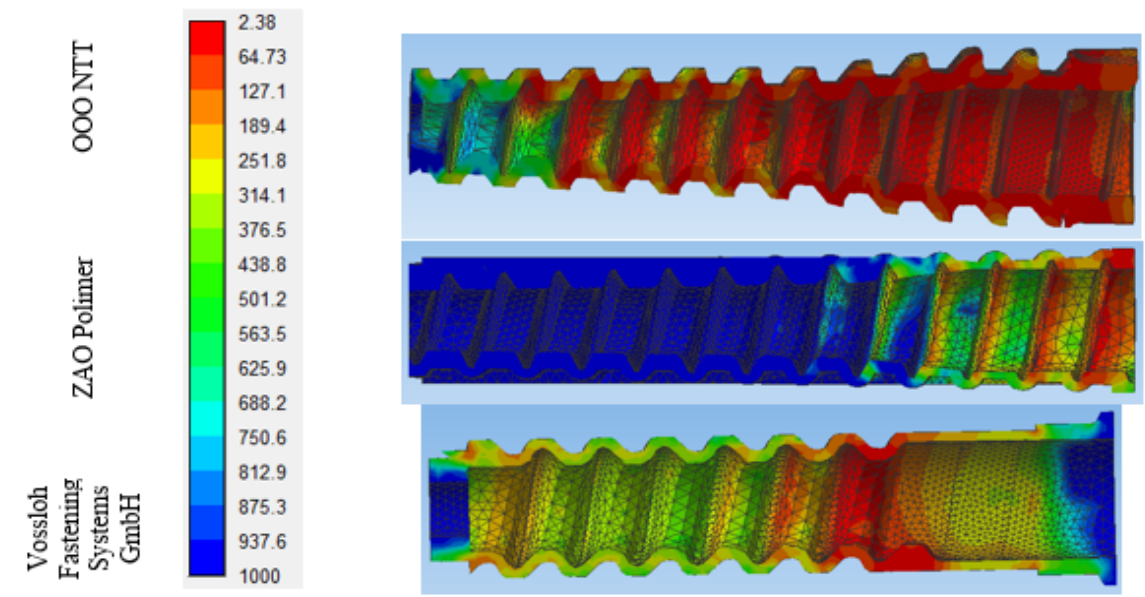

Figure 8. Safety factor distribution in the bodies of dowels, made by different manufacturers, at the operating load in a sleeper. 


\section{Architecture and Engineering Volume 4 Issue 1}

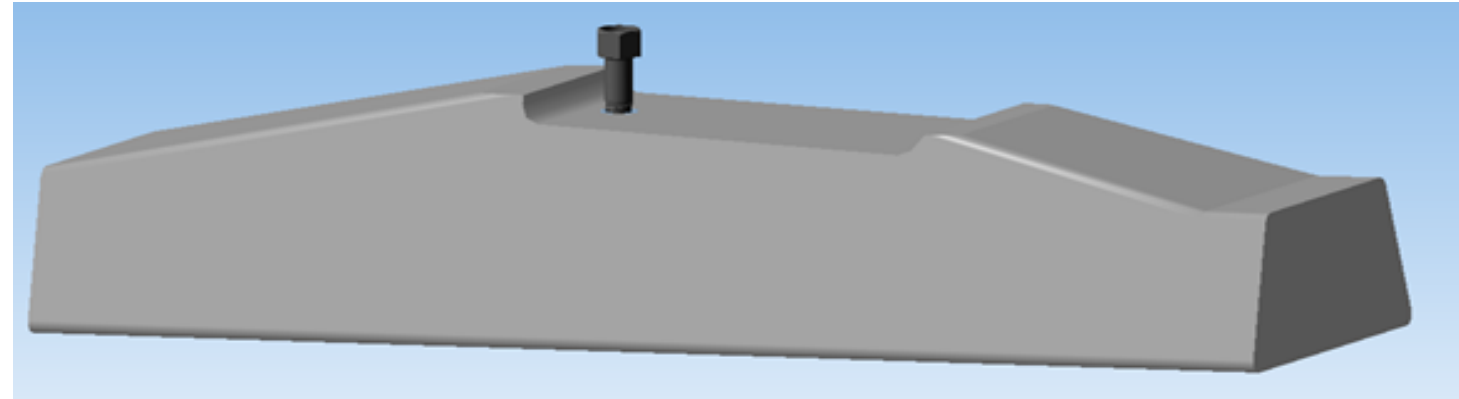

Figure 9. 3D model of an assembled half-sleeper with a dowel and a screw.

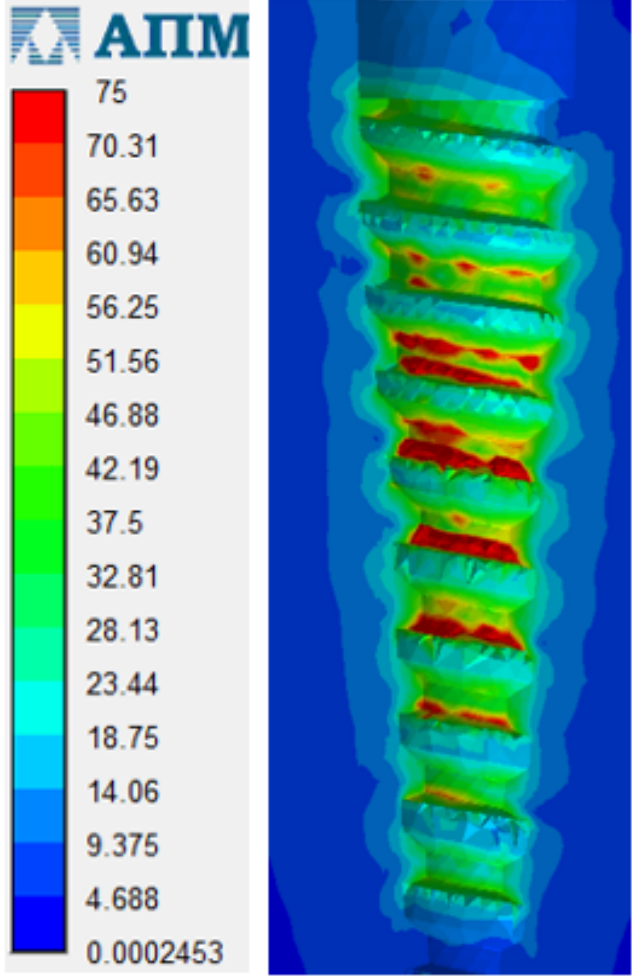

a)

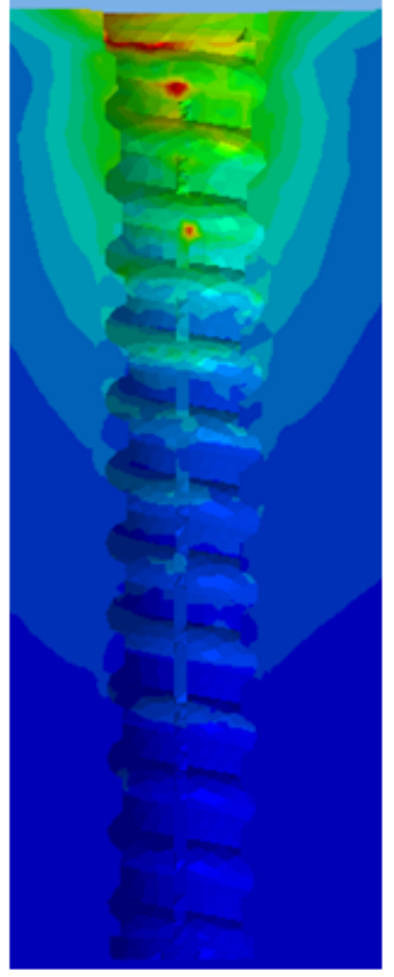

b)

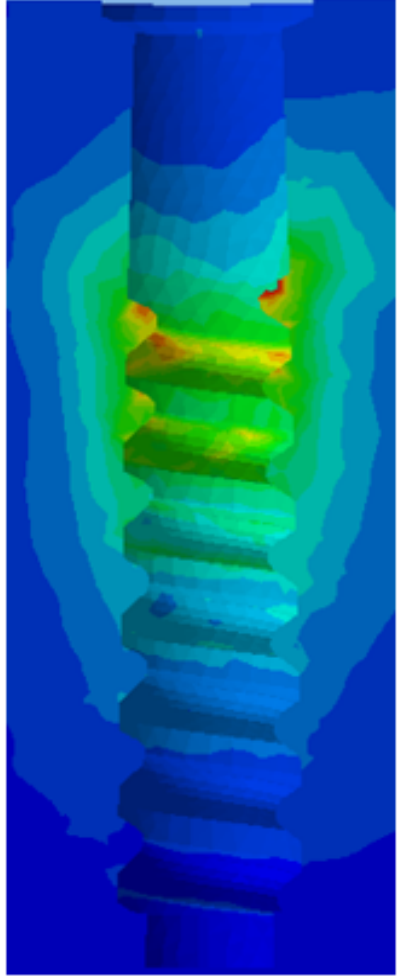

c)

Figure 10. Distribution of stresses in cross-sections of sleepers, coaxial with the dowel axis, with dowels made by: a - OOO NTT, b - ZAO Polimer, c - Vossloh Fastening Systems GmbH (MPa)

time along the outer surface of dowels, we will set normal fastening, which corresponds to a dowel embedded in concrete, and determine stresses occurring in the body of a dowel as well as safety factors. 8.

The calculation results are given in Figure 7 and Figure

As follows from Figure 7, stresses occurring in dowels during operation are significantly lower than those in tensile tests conducted according to the Regulations (Ministry of Railways, 2001). In particular, the maximum stress in the body of the dowel made by OOO NTT is 5 $\mathrm{MPa}$, by ZAO Polimer - $6 \mathrm{MPa}$, by Vossloh Fastening Systems $\mathrm{GmbH}-8 \mathrm{MPa}$ (in fragments).

Besides, the nature and zoning of stress distribution shall be paid attention to as they show that tests conducted according to Clause 4.6 (Ministry of Railways, 2001) have nothing in common with the actual operating conditions in terms of the stress nature and value.

The minimum safety factor value (Figure 8) for the dowel made by OOO NTT is 9.159 , by ZAO Polimer -5.54 , by
Vossloh Fastening Systems $\mathrm{GmbH}-11.53$. Therefore, strength characteristics of all dowels are beyond question and have significant safety factor in operation.

Intermediate conclusions:

1. The maximum values of stresses in all dowels during operation do not exceed $10 \mathrm{MPa}$, which is substantially less than those during tests conducted according to Clause 4.6 (Ministry of Railways, 2001).

2. The safety factor of dowels made according to the particular requirements (Ministry of Railways, 2003; Russian Railways, 2013; Karpushchenko, 2007) is significantly higher than 3 , which means that their strength characteristics correspond to the operating conditions with a significant safety factor.

General analysis of dowel structure impact on strength characteristics of sleepers

As resistance of reinforced concrete sleepers to dowel pulling-out with regard to sleepers with screw/ dowel rail fasteners has not been studied yet (Omarova, 
2010), we will analyze dowel structure impact on strength characteristics of sleepers. It should be noted that in order to determine strength characteristics of a screw/dowel rail fastener, corresponding tests are conducted according to Clause 4.9 (Russian Railways, 2016).

Using the method described in Section 1, we determined stresses occurring in sleepers with dowels of different structures at tests conducted according to Clause 4.9 (Russian Railways, 2016). For that purpose, 3D models of half-sleepers, used in tests, with dowels and screws were built (Figure 9).

According to the calculation results, stresses occurring in the bodies of dowels during such tests reach $70 \mathrm{MPa}$, which exceeds manifold the value of stresses occurring in dowels during operation.

The analysis of stresses (Figure 10) occurring in sleepers has shown that their maximum value reaches $75 \mathrm{MPa}$. In sleepers with dowels made by OOO NTT and Vossloh Fastening Systems $\mathrm{GmbH}$, the maximum stresses are in the sleeper body, which makes their redistribution possible and prevents dowel pulling-out from the sleeper.

Sleepers with dowels made by ZAO Polimer have maximum stresses in the upper face of a sleeper coaxially with the dowel axis, which significantly increases the probability of dowel pulling-out in case of extreme loads.

\section{Conclusions}

1. According to the calculations, in tensile tests of dowels conducted according to Clause 4.6 (Russian Railways, 2016), stresses of $85 . .100 \mathrm{MPa}$ occur in the bodies of all dowels under consideration, which considerablt exceed stresses appearing in dowels during operation, and the nature and distribution of such stresses do not correspond to those of operating stresses.

2. The maximum values of stresses in all dowels during operation do not exceed $10 \mathrm{MPa}$, which is substantially less than those during tests conducted according to Clause 4.6 (Russian Railways, 2016). The safety factor of dowels made according to the particular requirements (Russian Railways, 2017; VNIIZhT JSC (Railway Research Institute), 2011; Vossloh Fastening Systems $\mathrm{GmbH}, 2010$ ) is significantly higher than 3, which means that their strength characteristics correspond to the operating conditions with a significant safety factor.

3. During strength tests conducted according to 4.9 (Russian Railways, 2016), stresses occur in dowels, the nature of which corresponds to that of the operating stresses, and the value of which reaches $75 \mathrm{MPa}$, which exceeds manifold the value of stresses occurring in dowels during operation, which is why it is expedient to omit tensile tests conducted according to Clause 4.6 (Russian Railways, 2016) since they are redundant and do not reflect the actual conditions of dowel operation.

4. The analysis of stresses arising in sleepers with dowels by the manufacturers under consideration has shown that their limit value is $75 \mathrm{MPa}$. Besides, in sleepers with dowels by OOO NTT and Vossloh Fastening Systems $\mathrm{GmbH}$, the maximum stresses are in the sleeper body, which allows for their redistribution and prevents dowel pulling-out from a sleeper.

Sleepers with dowels made by ZAO Polimer have maximum stresses in the upper face of a sleeper coaxially with the dowel axis, which significantly increases the probability of dowel pulling-out in case of extreme loads. 


\section{References}

Akimov, V.P. (2006). Dowel fixing rail fastening. Patent RU56899U1.

Akimov, V.P. (2009a). Dowel fastening rail fastening assembly. Patent RU89532U1.

Akimov, V.P. (2009b). Dowel fastening rail fastening assembly. Patent RU89533U1.

Akimov, V.P. (2011). Fixing rail fastening assembly and used in the dowel and a screw. Patent RU104188U1.

Akimov, V.P. (2012). Dowel rail fastening. Patent RU113743U1.

Akimov, V.P., Krysanov, L.G., Serebrennikov, V.V., Ressina, N.V. (2008). Dowel fastening rail fastening assembly. Patent RU71662U1.

Alexandrova, V.V., Zaytseva, A.A. (2012). 3D-technologies and cognition programming. Information-measuring and Control Systems, 10 (5), pp. 61-65.

Alexandrova, V.V., Zaytseva, A.A. (2013). 3D modeling and 3D prototyping of complex space forms in the technology of cognitive programming. SPIIRAS Proceedings, 4 (27), pp. 81-92.

Bolshakov, V., Bochkov, A., Sergeev, A. (2010). 3D modeling in AUTOCAD, KOMPAS-3D, SOLIDWORKS, INVENTOR, T-FLEX: Training course. Saint Petersburg: Piter.

Borodin, S.P., Akimov, V.P., Ressina, N.V. (2013). Dowel and method of sleeper repair. Patent RU2482236C1.

Dydyshko, P.I. (2009). Analysis of current normative documents on design and maintenance of permanent way and roadbed. Vestnik of the Railway Research Institute, 6, pp. 15-21.

Karpushchenko, N.I. (2007). Issues and prospects of track structure improvement. The Siberian Transport University Bulletin, 16, pp. 42-62.

Karpushchenko, N.I., Antonov, N.I. (2003). Improvement of rail fasteners. Novosibirsk: Publishing House of the Siberian Transport University.

Kuznetsov, V.V., Eremushkin, A.A. (2006). Testing of rail fasteners continues. Railway Track and Facilities, 5, pp. 14-17.

Ministry of Railways (2001). Regulations on track facilities in the Russian Federation. Moscow: Ministry of Railways, p.79.

Ministry of Railways (2003). Specifications for repair and preventive and predictive maintenance of tracks. TsPT-53. Moscow: Ministry of Railways, p. 150.

Nikitin, D.A., Krivosheev, A.V., Kuznetsova, K.A. (2014). Dowel the mounting rail fastening assembly. Patent RU144345U1.

Nikitin, D.A., Vasilyev, A.Ye., Nikitina, L.V. (2009). Polypropylene composition. Patent RU2353635C1.

Nikitin, D.A., Vasilyev, A.Ye., Krivosheev, A.V., Kuznetsov, G.A. (2013). Dowel fastening rail fastening assembly. Patent RU127755U1.

Nikitina, L.V., Kosobudsky, I.D., Ushakov, N.M. (2013). Systems based on thermoplastic polymer with improved thermoplastic properties. In: Proceedings of the 10th International Scientific and Practical Conference with Virtual Participation "Scholarly Discussion: Problems of Mathematics, Physics, Chemistry and Biology", 10, pp. 66-70

Nikitina, L.V., Kosobudsky, I.D. (2016). Modification thermoplastic polymer nanoparticles of silica and properties of obtained composites. In: Proceedings of the International Conference "Prospective Polymeric Composite Materials. Alternative Technologies. Processing. Application. Environment" ("Kompozit-2016"), pp. 232-234.

Nikitina, L.V., Nikitin, D.A. (2013). Polypropylene modification with nano-sized silicon dioxide in order to change its mechanical properties. Science Review, 10, pp. 116-123.

Nikitina, L.V., Nikitin, D.A. (2015). Physical-mechanical properties of a composite polymeric material based on polypropylene doped with titanium dioxide nanoparticles. Scientific Thought, 3, pp. 359-363.

Omarova, G.A. (2010). Experimental studies of resistance to anchor and dowel pulling-out from reinforced concrete sleepers. In: Proceedings of the 6th International Scientific and Practical Conference "Recent Scientific Advances - 2010", 19, pp. 41-46.

Russian Railways (2013). Instructions for assembly, installation and operation of a track with a ZhBR-65PSh rail fastener with a polymeric rail pad on reinforced concrete sleepers. Available at: http://zddoc.ru/normdoc/instruktsiya-1815r-ob-utverzhdenii-i-vvedenii-v-deystvie-instruktsii-na-sborku-ukladku-i-ekspluatatsiyu-puti-s-razlichnyimi-modifikatsiyami-relsovogo-skrepleniya-zhbr-na-zhelezobetonnyih-shpalah/. (accessed on: 14.01.2019).

Russian Railways (2016). Dowel. Specifications TsP 369 TU-7. Available at: http://zakupki.gov.ru/223/purchase/public/download/download.html?id=40535008. (accessed on: 12.02.2019).

Russian Railways (2017).Plastic dowel for reinforced concrete sleepers (ShZ-D type) with ZhBR-65Sh screw/dowel rail fasteners. Specifications TU 2291-001-82660849-2012. Moscow: Russian Railways.

State Committee of the USSR for Standards (1980). State Standard GOST 11262-80. Plastics. Tensile test method. Moscow. 
VNIIZhT JSC (Railway Research Institute) (2011). Modernized plastic dowel for reinforced concrete sleepers (ShZ-D type) withr ZhBR-65Sh screw/dowel rail fasteners. Specifications TU 2291-207-01.00.000. Available at: zakupki.gov.ru/223/purchase/public/download/download.html?id=40194548. (accessed on: 11.01.2019).

Vossloh Fastening Systems GmbH (2010). Plastic dowel Sdü 25. Specifications TU 01.1.3419-2010. Available at: zakupki.gov. $\mathrm{ru} / 223 /$ purchase/public/download/download.html?id=32753536. (accessed on: 01.02.2019). 